\title{
Severe Obesity and selected risk factors in a sixth grade multi- racial cohort: the HEALTHY study
}

\author{
Marsha D. Marcus, PhD, \\ University of Pittsburgh School of Medicine \\ Tom Baranowski, PhD, \\ Baylor College of Medicine \\ Lynn L. DeBar, PhD, MPH, \\ Kaiser Permanente Center for Health Research \\ Sharon Edelstein, ScM, \\ George Washington University Biostatistics Center \\ Francine R. Kaufman, MD, \\ Keck School of Medicine, University of Southern California \\ Margaret Schneider, PhD, \\ University of California at Irvine
}

Anna Maria Siega-Riz, PhD, RD,

University of North Carolina School of Public Health

Myrlene A. Staten, MD,

National Institute of Diabetes and Digestive and Kidney Diseases, National Institutes of Health

Amy Virus, RD, and

Center for Obesity Research and Education, Temple University

\section{Zenong Yin, PhD \\ University of Texas at San Antonio}

\section{Abstract}

Purpose-To document the prevalence of severe obesity and associated risk in the HEALTHY cohort.

Methods-6,365 students were assessed at school-based screenings.

Results-6.9\% of students were severely obese. Severe obesity was associated with elevated cardiometabolic risk and race/ethnicity.

Conclusions-Severe obesity is common and requires preventive intervention.

\footnotetext{
C2010 Society for Adolescent Medicine. Published by Elsevier Inc. All rights reserved.

Corresponding Author and Reprint Requests: Marsha D. Marcus, PhD, Western Psychiatric Institute and Clinic, 3811 O'Hara Street, Pittsburgh, PA 15213, marcusmd@ upmc.edu, 412-246-6371, 412-246-6370 [FAX].

Conflicts of Interest: None.

Publisher's Disclaimer: This is a PDF file of an unedited manuscript that has been accepted for publication. As a service to our customers we are providing this early version of the manuscript. The manuscript will undergo copyediting, typesetting, and review of the resulting proof before it is published in its final citable form. Please note that during the production process errors may be discovered which could affect the content, and all legal disclaimers that apply to the journal pertain.
} 


\section{Keywords}

obesity; hyperinsulinism; glucose intolerance; hyperlipidemia; hypertension

\section{Introduction}

Increasing rates of pediatric obesity (1) have stimulated the development of prevention programs to minimize obesity and related morbidities. HEALTHY was an NIDDK-funded, three-year intervention designed to reduce risk factors for type 2 diabetes [i.e., Body Mass Index $(B M I) \geq 85^{\text {th }}$ percentile for age and sex, fasting glucose $\geq 100 \mathrm{mg} / \mathrm{dL}$, and fasting insulin $\geq 30 \mu \mathrm{U} / \mathrm{mL}$ ] in a diverse sample of US school children. We recently reported baseline data for the HEALTHY cohort of $6,3586^{\text {th }}$ grade students, which documented high rates of obesity and diabetes risk factors (2). In this report, we focus on baseline data relating to the sub-group of students with severe obesity [BMI $\geq 99^{\text {th }}$ percentile for age and sex (3)]. The prevalence of severe obesity also has increased (4), and approximately $4 \%$ of American children have a BMI $\geq 99^{\text {th }}$ percentile (3). Severe obesity is a robust predictor of medical and psychosocial morbidity, as well as persistence of obesity into adulthood (4). Thus, we examined rates of severe obesity in the HEALTHY $6^{\text {th }}$ grade cohort, and the relation between severe obesity, and cardiometabolic risk factors and race/ethnicity.

\section{Methods}

Forty-two middle schools with $\geq 50 \%$ of minority children or students eligible for free/ reduced lunch were recruited at 7 US centers. Sixth grade students were invited to health screenings in fall 2006; $57.6 \%$ of students enrolled. The study was approved by the Institutional Review Boards at each site, and parent consent and child assent were obtained.

Assessment methods were reported previously (5). Height, weight, waist circumference and blood pressure were measured, and fasting blood draws were obtained to assess metabolic (glucose, insulin) and additional cardiovascular (total cholesterol, LDL, HDL, triglycerides) risk factors. BMI percentile for age and sex was calculated using the CDC program $(6,7)$. Youth with BMI $\geq 85^{\text {th }}$ but $<95^{\text {th }}$ percentile were classified as overweight and those $\geq 95^{\text {th }}$ but $<99^{\text {th }}$ percentile as obese. Students with BMI $\geq 99^{\text {th }}$ percentile were classified as severely obese. Blood was analyzed by Northwest Lipid Metabolism and Diabetes Research Laboratories, University of Washington, Seattle.

Ethnicity and race were self-reported. Students checking 'Hispanic or Latino' ethnicity were classified as Hispanic ( $\mathrm{n}=3376)$; non-Hispanics choosing only 'Black or African American' race were classified as Black ( $\mathrm{n}=1254)$; non-Hispanics choosing only 'White' race were White ( $\mathrm{n}=1197)$; all other response categories ( $\mathrm{n}<140$ each) were combined into 'Other.' A parent or guardian reported family history of diabetes.

Generalized linear mixed models (SAS Proc GLIMMIX) that included a random effect for school to adjust for clustering of children within schools were used to examine the relation between risk factors, and levels of BMI and race/ethnicity categories.

\section{Results}

Students $(\mathrm{N}=6,358)$ averaged 11.8 years $(\mathrm{SD}=0.6)$ and $48 \%$ were male. The number and percent of students in the BMI categories are presented in Table 1. There were 441 students $(6.9 \%)$ in the severely obese category (Mean BMI $=35.2 \mathrm{~kg} / \mathrm{m}^{2} \pm 3.7$ ). Rates of severe obesity differed by sex $(7.5 \%$ of boys and $6.4 \%$ of girls, $p=0.007)$. Severe obesity also 
varied by ethnic group with rates of $4.9 \%, 8.0 \%$, and $7.3 \%$ for White, Black and Hispanic youth, respectively ( $<$.0001). Rates of severe obesity also differed as a function of race/ ethnicity and sex $(\mathrm{p}=0.01)$ with the highest rates observed in Black girls $(8.7 \%)$ and Hispanic boys (8.2\%), and lowest rates among White girls (4.1\%) and boys (5.8\%).

Table 2 shows the percent of students with a family history of type 2 diabetes and cardiometabolic risk factors within BMI percentile categories (all p's <0.001). In general, the prevalence of risk increased as a function of BMI percentile. Severely obese children were more likely than those with more moderate obesity (i.e., BMIs $95-<99^{\text {th }}$ percentile) to have a family history of diabetes, elevated waist circumference and insulin levels, and low HDL-cholesterol and high blood pressure. Table 2 also documents that among severely obese youth, risk varied as a function of racial/ethnic group, with Hispanic students having highest rates of elevated insulin, and White students having highest rates of elevated total cholesterol and blood pressure.

\section{Discussion}

Data from the HEALTHY study document that $6.9 \%$ of a diverse sample of US sixth graders were severely obese, a rate notably higher than the 4\% reported among 5-17 year old Black and White children participating in the Bogalusa Heart Study (3). As shown in previous studies (4), the prevalence of severe obesity varies markedly by race/ethnicity group. In the current study, we observed rates of $4.9 \%, 8.0 \%$, and $7.3 \%$ for White, Black and Hispanic youth, respectively, which are higher across all racial/ethnic groups than those derived from the 1999-2002 NHANES data (4). Although differences in sampling may explain differences in prevalence across studies, the current findings provide compelling evidence of high rates of severe obesity in American middle school children. Indeed, the average BMI of the severely obese children in the HEALTHY cohort was $35.2 \mathrm{~kg} / \mathrm{m}^{2}$, a level consistent with adult Class 2 obesity (8).

Among severely obese children, patterns of risk varied by race/ethnicity, which replicates findings of previous investigations (9). Specifically, Hispanic students had highest rates of risk for type 2 diabetes, White youth had a differentially high risk for elevated total cholesterol and high blood pressure, while Black youth were less likely to have low HDL or elevated triglycerides. These data provide additional documentation of variations in risk across racial/ethnic groups and demonstrate that even among severely obese youth, there are different patterns of risk in children of different racial/ethnic backgrounds.

Rates of severe obesity have increased more rapidly than those of moderate obesity in adults (10), and the current investigation suggests that there may be a similar pattern among US public school students. Severe pediatric obesity is thought to require aggressive intervention, which raises the question of whether school-based prevention programs such as HEALTHY will benefit this sub-group of children. Thus, it will be important to evaluate whether public health efforts that target multiple environmental and behavioral factors to decrease pediatric overweight, in general, also will reduce increases in severe obesity.

\section{Acknowledgments}

This work was completed with funding from NIDDK/NIH grant numbers U01-DK61230, U01-DK61249, U01DK61231, and U01-DK61223 to the STOPP-T2D collaborative group, with additional support from the American Diabetes Association.

\section{HEALTHY Acknowledgments}

We wish to thank the administrations, faculty, staff, students, and their families at the middle schools and school districts that participated in the HEALTHY study. 
The following individuals and institutions constitute the HEALTHY Study Group $(*$ indicates principal investigator or director):

STOPP-T2D Study Chair Childrens Hospital Los Angeles: F.R. Kaufman

Field Centers Baylor College of Medicine: T. Baranowski*, L. Adams, J. Baranowski, A. Canada, K.W. Cullen, M.H. Dobbins, R. Jago, A. Oceguera, A.X. Rodriguez, C. Speich, L.T. Tatum, D. Thompson, M.A. White, C.G. Williams Oregon Health \& Science University: L. Goldberg*, D. Cusimano, L. DeBar, D. Elliot, H.M. Grund, K. Kuehl, S. McCormick, E. Moe, J.B. Roullet, D. Stadler Temple University: G.D. Foster* (Steering Committee Chair), J. Brown, B. Creighton, M. Faith, E.G. Ford, H. Glick, S. Kumanyika, J. Nachmani, J. Rosen, L. Rosen, S. Sherman, S. Solomon, A. Virus, S.L. Volpe, S. Willi University of California at Irvine: D. Cooper*, S. Bassin, S. Bruecker, D. Ford, P. Galassetti, S. Greenfield, J. Hartstein, M. Krause, N. Opgrand, Y. Rodriguez, M. Schneider University of North Carolina at Chapel Hill: J.S. Harrell*, A. Anderson, T. Blackshear, J. Buse, J. Bridgman, A. Gerstel, C. Giles, W. Hall, A. Jessup, P. Kennel, R. Matthews, R.G. McMurray, D. Rubin, A.M. Siega-Riz, M. Smith, A. Steckler, A. Zeveloff University of Pittsburgh: M.D. Marcus*, M. Carter, S. Clayton, B. Gillis, K. Hindes, J. Jakicic, R. Meehan, R. Noll, T. Songer, J. Vanucci, E.M. Venditti University of Texas Health Science Center at San Antonio: R. Treviño*, A. Garcia, D. Hale, A.E. Hernandez, I. Hernandez, C. Mobley, T. Murray, K. Surapiboonchai, Z. Yin

Coordinating Center George Washington University: K. Hirst*, K.L. Drews, S. Edelstein, L. El ghormli, L.S. Firrell, M. Huang, P.K. Feit, S.L. Mazzuto, T. Pham, A. Wheeler

Project Office National Institute of Diabetes and Digestive and Kidney Diseases: B. Linder*, C. Hunter, M. Staten

Central Blood Laboratory University of Washington Northwest Lipid Metabolism and Diabetes Research Laboratories: S.M. Marcovina*

\section{References}

1. Ogden CL, Flegal KM, Carroll MD, Johnson CL. Prevalence and trends in overweight among US children and adolescents, 1999-2000. JAMA 2002;288:1728-1732. [PubMed: 12365956]

2. HEALTHY Study Group. Risk factors for type 2 diabetes in a 6th grade multi-racial cohort: the HEALTHY study. Diabetes Care 2009;32:953-955. [PubMed: 19196888]

3. Freedman DS, Mei Z, Srinivasan SR, Berenson GS, Dietz WH. Cardiovascular risk factors and excess adiposity among overweight children and adolescents: the Bogalusa Heart Study. J Pediatr 2007;150:12-17. [PubMed: 17188605]

4. Freedman DS, Khan LK, Serdula MK, Ogden CL, Dietz WH. Racial and ethnic differences in secular trends for childhood BMI, weight, and height. Obesity 2006;14:301-308. [PubMed: 16571857]

5. STOPP-T2D Prevention Study Group. Presence of diabetes risk factors in a large US eighth-grade cohort. Diabetes Care 2006;29:212-217. [PubMed: 16443862]

6. Centers for Disease Control National Center for Health Statistics. A SAS program for the CDC growth charts. available online at http://www.cdc.gov/nccdphp/dnpa/growthcharts/sas.htm

7. Centers for Disease Control National Center for Health Statistics. 2000 CDC growth charts for the United States. available online at http://www.cdc.gov/growthcharts

8. National Institutes of Health. Clinical Guidelines on the Identification, Evaluation and Treatment of Overweight and Obesity in Adults: The Evidence Report. Washington, DC: National Institutes of Health; 1998.

9. Weiss R, Dziura J, Burgert TS, Tamborlane WV, Taksali SE, Yeckel CW, et al. Obesity and the metabolic syndrome in children and adolescents. New Engl J Med 2004;350:2362-74. [PubMed: 15175438]

10. Sturm R. Increases in morbid obesity in the USA: 2000-2005. Public Health 2007;121:492-496. [PubMed: 17399752] 


\begin{tabular}{|c|c|c|c|c|c|c|c|}
\hline & & 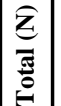 & $\underset{⿱}{\stackrel{5}{I}}$ & $\mathscr{\&}$ & $\overrightarrow{6}$ & $\frac{t}{\sim}$ & లె \\
\hline & & 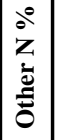 & $\begin{array}{l}\hat{y} \\
0 \\
b \\
o \\
0 \\
0\end{array}$ & \begin{tabular}{|l|}
$\infty$ \\
2 \\
$\infty$ \\
0 \\
0 \\
$i n$
\end{tabular} & \begin{tabular}{|l|}
$\infty$ \\
2 \\
$\infty$ \\
0 \\
0 \\
$i n$
\end{tabular} & 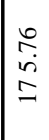 & ลิ \\
\hline & $\stackrel{n}{\vdots}$ & 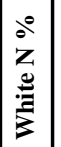 & $\begin{array}{l}\bar{m} \\
\stackrel{8}{ } \\
\bar{m} \\
m\end{array}$ & 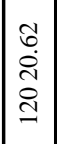 & \begin{tabular}{|l|}
$\mathfrak{n}$ \\
$\alpha$ \\
$\dot{ \pm}$ \\
$\infty$ \\
$\infty$
\end{tabular} & $\begin{array}{l}\text { I } \\
\stackrel{+}{+}\end{array}$ & $\stackrel{\sim}{\infty}$ \\
\hline & & 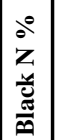 & 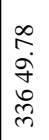 & $\begin{array}{l}\vec{F} \\
\stackrel{\vec{g}}{\vec{m}} \\
\overrightarrow{\underline{m}}\end{array}$ & 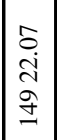 & \begin{tabular}{|l} 
in \\
in \\
in
\end{tabular} & $\frac{2}{6}$ \\
\hline 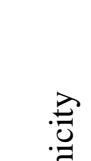 & & 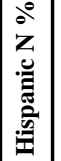 & 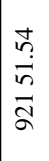 & 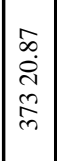 & 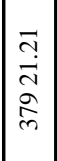 & 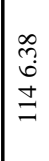 & $\stackrel{\infty}{\stackrel{\infty}{=}}$ \\
\hline 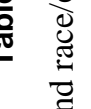 & & 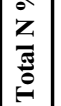 & 导 & $\begin{array}{l}0 \\
i n\end{array}$ & $\frac{5}{g}$ & సิ & 岕 \\
\hline 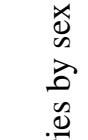 & & 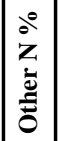 & 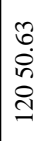 & 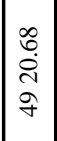 & 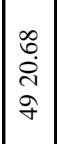 & $\mid \begin{array}{l}\sigma \\
0 \\
\infty \\
2 \\
2\end{array}$ & $\hat{\tilde{\lambda}}$ \\
\hline $\begin{array}{l}0 \\
\stackrel{0}{0} \\
\tilde{J} \\
0 \\
\Xi\end{array}$ & & 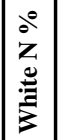 & 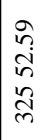 & 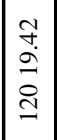 & 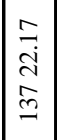 & $\begin{array}{l}\tilde{\infty} \\
\tilde{n} \\
\tilde{n} \\
\end{array}$ & $\frac{\infty}{6}$ \\
\hline $\begin{array}{l}\sum_{0}^{0} \\
\stackrel{0}{E}\end{array}$ & & 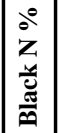 & $\begin{array}{l}\hat{n} \\
\frac{\hat{\sigma}}{m}\end{array}$ & 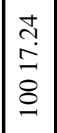 & 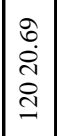 & $\begin{array}{l}\hat{a} \\
\stackrel{0}{7} \\
7\end{array}$ & $\stackrel{\infty}{\infty}$ \\
\hline 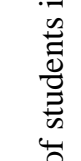 & 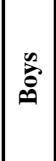 & 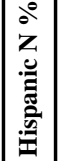 & 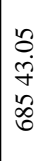 & \begin{tabular}{|l|}
$m$ \\
$\stackrel{2}{2}$ \\
$\stackrel{2}{\rho}$ \\
\end{tabular} & 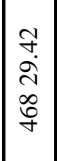 & $\mid \begin{array}{l}\hat{\jmath} \\
\infty \\
\tilde{m}\end{array}$ & 究 \\
\hline 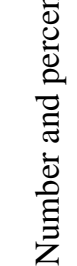 & & 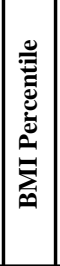 & 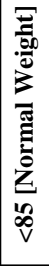 & 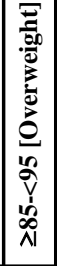 & 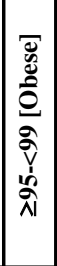 & 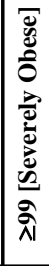 & 产 \\
\hline
\end{tabular}




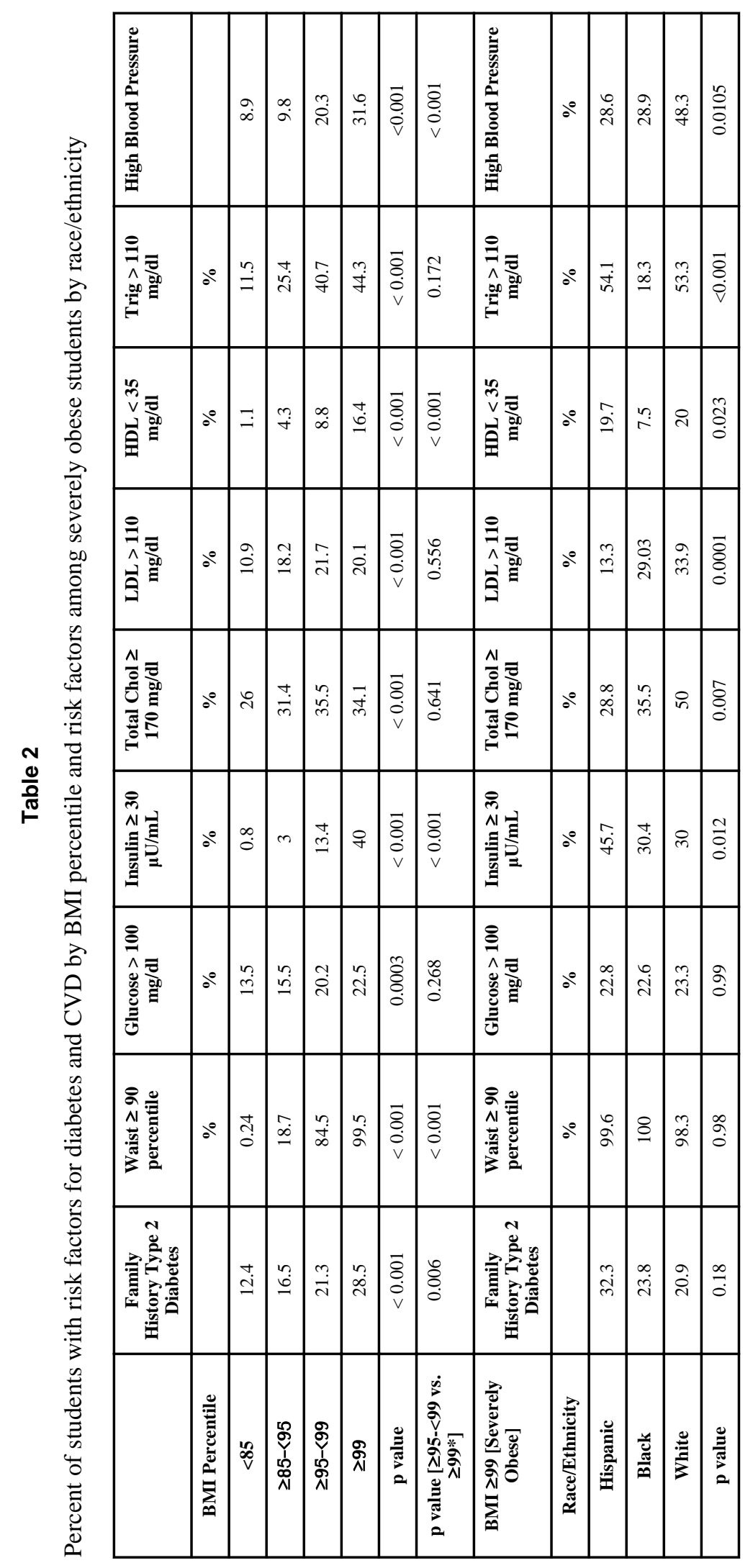

